\title{
Factors Influencing Construction Productivity in Afghanistan
}

\author{
Sebghatullah Karimi ${ }^{1}$ and Kassim Gidado ${ }^{2}$
}

\begin{abstract}
As in many developing economies, productivity is an issue of particular importance in Afghanistan. This is considered as one of the strategic goals of the Afghanistan National Development Strategy (ANDS) to carry out the country's development cycle further than the post-conflict situation. There is a lack of sufficient research on construction productivity in Afghanistan, but going by the example of other countries it can be assumed that any effort directed to improving productivity will greatly enhance the country's chances of realizing its strategic development goals. This paper describes a study conducted with the aim of identifying factors influencing construction productivity in Afghanistan. Data and information were collected through a structured questionnaire survey. Utilizing the relative importance index ranking techniques, the identified factors were prioritized for further detailed analyses. The result indicates the six most significant factors influencing construction productivity in Afghanistan are: Security (Crime, theft and disorder), Corruption, Poor Scheduling and Coordination, Construction method, Low quality of raw materials, and Payment delays. Based upon these findings, the paper recommends the key drivers for changing the productivity level in the Afghanistan construction industry
\end{abstract}

Keywords: Afghanistan, construction productivity, relative index

\section{Introduction}

Construction industry forms a substantial portion of any nations economic output. Improving and developing of methods and techniques to increase the economic output of construction industry are significant and important for any nation. Therefore, construction productivity improvement is one of the key focus areas of many countries and governments across the world.

The characteristics of the construction industry are cost overruns and repeated delays, which are potentially more serious in developing countries than in developed countries (Mansfield et al., 1994; Altaf, 1979). Similar to other developing countries such as Indonesia (Kaming et al., 1997), Iran (Zakeri et al., 1996), Malaysia (Yong, 1987), Nigeria (Aniekwu and Okpala, 1988; Mansfield et al., 1994) and Saudi Arabia (Assaf et al., 1995), the construction industry in Afghanistan is also experiencing productivity problems.

The statistics for construction industry in Afghanistan illustrates that the industry has a share of 25 percent in GDP and ranked third in the country economy. The construction industry share in GDP is reported 9.2 percent between 2008/09 and it has been growing at a rate of 10 percent between 2007/08 and 2008/09 (AISA, 2008). Despite the fact that the construction industry represents a substantial portion of Afghanistan economy, the

1 Kabul Polytechnic University, Construction Faculty, Karta-e- Mamorin, Districts \#5, Kabul, Afghanistan. E-mail:sebghatullah_karimi@yahoo.com

2 University of Brighton, School of Environment and Technology, Cockcroft Building, Lewes Road, Brighton, East Sussex BN2 4GJ. UK 
performance and improvement in construction productivity over the past years has been underestimated. There are undue cost overruns, delays and loose of productivity associated with the delivery of major infrastructure projects such as power plants and roads. According to SIGAR (2010) the main concerns of construction activities in Afghanistan is lack of security, lack of sustainability, and lack of management capability in private and public sectors. Inadequate improvement in construction productivity leads to the increase of construction cost, consequently, cause to unfavourable social consequences and declining work for the construction industry.

Despite of the vital role of construction activities in the country, little researches have been carried out on construction productivity, and management techniques and productivity improvement rarely discussed in academia. Going by the example of other countries it can be assumed that any effort directed to improving productivity will greatly enhance the country's chances of realizing its developments goals. This research, therefore, aims to identify factors influencing construction productivity in Afghanistan. The rationale of the paper is that productivity cannot be improved without identifying critical weaknesses in the existing practice. The research intends to create the foundation for further study of construction productivity measurement and improvement in Afghanistan, which aims to lead to overall productivity improvement.

\section{Literature Review}

The concept of Productivity is not new and has existed for a long time. It has been applied in many circumstances at various level of aggregation in the past two centuries, especially, in relation to economic systems (Tangen, 2005). Productivity represents one of the most important basic variables governing economic production activities (Singh et al., 2000). Therefore, improving productivity is one of the strategic goals of any profit-oriented organization in order to convert the resources effectively and efficiently into marketable products and determine business profitability (Wilcox et al, 2000).

Researchers directed considerable efforts for the definition of productivity and different approaches adopted for the term. Productivity has been generally defined as the ratio of total output to total input, and the capacity to produce and the state of being productive and effective (Olomolaiye et al, 1998). Productivity can also be explained as the ability to satisfy the market needs for goods and services with a minimum of total resource consumption.

A study of the factors, whether positively or negatively is necessary for productivity improvement. In order to eliminate or control those factors that affect productivity negatively and making use of those which have a positive impact (Lema, 1995). Several researchers have investigated the factors affecting construction productivity. Despite such intensive investigation, researchers have not agreed on a universal set of factors with significant influence on productivity; or any agreement has been reached on the classification of these factors. Therefore, it is argued that factors affecting construction productivity are rarely constant, and may vary from country to country, from project to project or even within the same project, depend on circumstances (Olomolaiye et al, 1998).

However, Herbsman and Ellis (1990) divided construction productivity influence factors (CPIFs) into technological and administrative factors. The technological factors mostly project design related factors and administrative group factors are related to the management and to the construction of project. CPIFs that can be determined at the preconstruction stage are technological factors. On the other hand, if the value of CPIFs cannot be determined at the preconstruction stage are administrative factors. Another approach to the classification of construction productivity influence factors is suggested by 
Olomolaiye et al (1998) as external and internal factors. The later classification is adopted in for the study.

\section{Research Design and Methodology}

The survey presents 68 productivity related factors generated on the basis of a related research work on construction productivity. These factors were divided into 7 groups based on previous literature in relation to Afghanistan political, economical and social environments, as well as based on similar case studies in Gaza Strip (Enshassi et al, 2007), and Iran (Zakeri et al, 1996). These groups of factors are; external factors, procurement related factors, manpower factors, management factors, design related factors, project related factors, and materials and tools factors.

The respondents were asked to rank the factors according to the degree of influence, using Likert Scale on a scale of 1 to 5. For analysing of data by ordinal scale, an Importance Index was applied. This index was used for identifying of factors affecting construction productivity in Gaza Strip (Enshassi et al, 2007), Thailand (Makulsawatudom and Margaret, 2001), Iran (Zakeri et al, 1996), Malaysia (Abdul Kadir et al, 2005). The importance index was calculated by the following equation (Lim et al, 1995)

Where;

$$
\text { Importance index }=\frac{5 n 5+4 n 4+3 n 3+2 n 2+n 1}{5(n 1+n 2+n 3+n 4+n 5)}
$$

Number of respondents who answered: $\mathrm{n}_{1}$ very low influence, $\mathrm{n}_{2}$ low influence, $\mathrm{n}_{3}$ average influence, $\mathrm{n}_{4}$ high influence, and $\mathrm{n}_{5}$, very high influence. Data for this study were collected through a structured survey questionnaire administrated to 50 participants. A total of 16 questionnaires were completed by 11 contractors, 2 consultants, 2 consultants and contractors, and 1 client, represented a response rate of 32 percent. Of those 16 construction stakeholders, the majority were involved in public projects and Housing (Table 1).

Table 1. Type of Projects Undertaken by the Companies

\begin{tabular}{lcc}
\hline Type of Projects & Weighting & Percentage (\%) \\
\hline Public facilities & 15 & 38 \\
\hline Housing & 10 & 25 \\
\hline Industrial & 2 & 5 \\
\hline Commercial & 5 & 13 \\
\hline Military facilities & 3 & 8 \\
\hline Total & 40 & 100 \\
\hline
\end{tabular}

\section{Characteristic of Respondents}

The results in Table 2 indicate the respondents working experience in the construction industry. The majority of respondents have 2 to 5 years experience and only 13 per cent have an experience of 15 years and above.

Table 2. Respondents Working Experience

\begin{tabular}{lcclcc}
\hline Years of Experience & Number & \% & Years of Experience & Number & \% \\
\hline 2 to 5 & 9 & 56 & 10 to 15 & 2 & 13 \\
\hline 5 to 10 & 3 & 19 & 15 and above & 2 & 13 \\
\hline
\end{tabular}


Due to the complexity of the term Productivity, careful attention is paid during the selection of construction stakeholders to ensure the reliability and validity of the data. Respondent's position in table 3 indicates that most of them understand the term construction productivity. In this research, 3 university lecturers, 2 project managers, 1 construction manager, 1 architect, 2 design engineers, 2 senior civil engineers, 1 surveyor, and others are contributed to the survey (Table 3 ).

Table 3. Respondents Position

\begin{tabular}{lcclcc}
\hline Position & Number & \% & Position & Number & \% \\
\hline Project managers & 2 & 13 & Architect & 1 & 6 \\
\hline Construction managers & 1 & 6 & University lecturers & 3 & 19 \\
\hline Senior civil engineer & 2 & 13 & Surveyor & 1 & 6 \\
\hline Design engineer & 2 & 13 & others & 4 & 25 \\
\hline
\end{tabular}

\section{Results and Findings}

68 factors have been identified negatively affecting construction productivity in Afghanistan, and ranked according to their relative importance. These factors have been classified into seven groups. The Importance index (I) for all factors was calculated and then the group index was calculated by taking the average of factors in each group.

\section{External Factors}

The results in Table 4 demonstrate that 11 factors under the external factors group negatively influence construction productivity in Afghanistan. Security with an importance index of 0.9375 is ranked as the first factor that has a high influence on construction productivity, ranked in position of 1 of all 68 factors. This result is supported by UNODC and UNOPS (2007), where they found 'Security' as the first constraint, which have negatively and significantly influenced their program during the prison construction and rehabilitation in the country. Based on a survey of construction firms by The World Bank (2009b), security (crime, theft, and disorder) ranked as one of the most 6 important factors that affect construction activities in Afghanistan. The second factor that has a high impact on productivity is corruption with an importance index of 0.8714 , ranked in position of 2 of all factors. This result is justified as Afghanistan in terms of its ability to control corruption, is ranked in lowest $0_{\text {th }}-10_{\text {th }}$ percentile alongside Bangladesh, Somalia and Zimbabwe. Construction activities are vulnerable to corruption, especially the procurement process. In Afghanistan, it seems to be common practice to win a bid with offering bribe, without consideration of company's capability and capacity (World Bank, 2009a).

Table 4. Ranking Factors under External Group

\begin{tabular}{lll}
\hline External Factors & Imp Index & Rank \\
\hline Security (Crime, theft and disorder) & 0.9375 & 1 \\
\hline Corruption & 0.8714 & 2 \\
\hline Market inflation & 0.7500 & 3 \\
\hline Access to Finance & 0.7375 & 4 \\
\hline Augmentation of Government regulations & 0.7250 & 5 \\
\hline Judicial system for construction disputes & 0.6667 & 6 \\
\hline Access to utilities (Electricity, Water) & 0.6625 & 7 \\
\hline
\end{tabular}




\begin{tabular}{lll}
\hline Local people cooperation (warlords influence) & 0.6375 & 8 \\
\hline Inclement Weather (work stoppage of one day or more) & 0.6250 & 9 \\
\hline Access to land & 0.6125 & 10 \\
\hline Natural disaster (floods, hurricane, landslide) & 0.5429 & 11 \\
\hline
\end{tabular}

\section{Procurement Related Factors}

Table 5 shows 4 factors in the group related to procurement. Payment delay and type of project bidding and award (negotiation, lowest bidder) are ranked, respectively, in position of first and second of procurement factors with an importance index of 0.8125 and 0.7714 . Project cycle (tendering process) was ranked third; and type of construction contract was ranked fourth.

Payment delay is ranked in position of 6 of all 68 factors affecting construction productivity in Afghanistan. This result is supported by the World Bank (2009a) that they found the lengthy and complex disbursement and payment process discourages some qualified contractors from bidding for jobs. Moreover, the payment system is vulnerable to manipulation and corruption. The process can take as long as four to five months, with technical and non-technical delays.

Table 5. Ranking of Factors under Procumbent Group

\begin{tabular}{lll}
\hline Procurement Related Factors & Imp Index & Rank \\
\hline Payment delay & 0.8125 & 1 \\
\hline Type of project bidding and award (negotiation, lowest & 0.7714 & 2 \\
\hline Project cycle (tendering process) & 0.7250 & 3 \\
\hline Types of construction contract & 0.6125 & 4 \\
\hline
\end{tabular}

\section{Manpower Related Factors}

Table 6 illustrates the ranking of the 16 factors in the group related to manpower. The results indicate that the most important factors negatively affecting the productivity of manpower are lack of competition, followed by lack of skill and Communication Problems with Foreign Workers. This result is supported by Rojas and Aravareekul (2003), who they found that both management skills and manpower issues are two areas with the greatest potential for affecting productivity in construction.

Table 6. Ranking Factors under Manpower Group

\begin{tabular}{lll}
\hline Manpower Related Factors & Imp Index & Rank \\
\hline Lack of competition & 0.7250 & 1 \\
\hline Lack of Skill (Lack of labour experience) & 0.7125 & 2 \\
\hline Communication Problems With Foreign Workers & 0.6571 & 3 \\
\hline Difficulty in Recruitment of Supervisors & 0.6375 & 4 \\
\hline Fatigue & 0.6250 & 5 \\
\hline Changing Supervisors & 0.5625 & 6 \\
\hline High Rate of Labour Turnover & 0.5467 & 7 \\
\hline Difficulty in Recruitment of Workers & 0.5375 & 8 \\
\hline Misunderstanding among labour & 0.5375 & 9 \\
\hline Labour personal problems & 0.5375 & 10 \\
\hline Absenteeism at Worksite & 0.5333 & 11 \\
\hline
\end{tabular}




\begin{tabular}{lll}
\hline Labour disloyalty & 0.5250 & 12 \\
\hline Labour dissatisfaction & 0.5200 & 13 \\
\hline Changing Workers & 0.5000 & 14 \\
\hline Labour Disruption (e.g. manpower shortages , strikes) & 0.5000 & 15 \\
\hline Increase of labourer age & 0.4875 & 16 \\
\hline
\end{tabular}

\section{Management Related Factors}

All management factors have a high influence on construction productivity, and were ranked according to their importance as indicated in Table 7. Poor scheduling and coordination with an importance index of 0.8375 , is ranked in position of 1 , which has a high impact on construction productivity, followed by financial incentives and lack of equipment in position of 2 and 3 of management group. These three factors, respectively, ranked in position 3,11 and 16 of all 68 factors affecting construction productivity in Afghanistan. The result indicates that Poor Scheduling and Coordination is ranked as the third important factor after security in corruption. This is to confirm that scheduling (programming) and coordination of construction activities play an important role in completion of any construction projects in time and on budget and should be on the top focus of construction firms.

Table 7. Ranking Factors under Management Group

\begin{tabular}{lll}
\hline Management Factors & Imp Index & Rank \\
\hline Poor Scheduling and Coordination & 0.8375 & 1 \\
\hline Financial Incentives & 0.7875 & 2 \\
\hline Lack of Equipment & 0.7625 & 3 \\
\hline Transportation and mobilization to construction site & 0.7625 & 4 \\
\hline Lack of training sessions for labours & 0.7333 & 5 \\
\hline Stoppages because of insolvency of subcontractors / suppliers & 0.7125 & 6 \\
\hline Availability of project managers & 0.7125 & 7 \\
\hline Inspection Delays & 0.7067 & 8 \\
\hline Stoppages because of disputes with owners / consultants & 0.6875 & 9 \\
\hline Stoppages because of work being rejected by consultants & 0.6500 & 10 \\
\hline Misunderstanding between labour/ superintendents & 0.6429 & 11 \\
\hline Stop work orders because of infringements of government & 0.6400 & 12 \\
\hline Interference from other crew trades or other crew members & 0.6400 & 13 \\
\hline Lack of labour surveillance & 0.6375 & 14 \\
\hline Lack of periodic meeting with labour & 0.6250 & 15 \\
\hline Work Overtime & 0.5875 & 16 \\
\hline Stop-work orders because of site accidents & 0.5875 & 17 \\
\hline Crew Size & 0.5500 & 18 \\
\hline Lack of places for eating and relaxation for labours & 0.5067 & 19 \\
\hline
\end{tabular}

\section{Design Factors}

All design factors have a high impact on productivity, and were ranked according to their importance in Table 8. Drawings and Specification Alteration during Execution is the most important factor in design group, ranked in position 7 of all 68 factors with an importance index value of 0.8125 . This result is justified as the alteration of drawings and specifications during execution requires additional time for adjustments of resources and manpower so the change can be met. Moreover, according to Enshassi et al (2007), labour 
morale is also affected by extensive numbers of changes. This result is also supported by Thomas (1999), who stated that there is a $30 \%$ loss of efficiency when work changes are being performed.

Table 8. Ranking Factors under Design Group

\begin{tabular}{lll}
\hline Design Factors & Imp Index & Rank \\
\hline Drawings and specifications alteration during execution & 0.8125 & 1 \\
\hline Buildability (ease of construction) & 0.7875 & 2 \\
\hline Rework & 0.7875 & 3 \\
\hline Specification and standardisation & 0.7500 & 4 \\
\hline Supervisors' absenteeism & 0.7333 & 5 \\
\hline Construction law and regulation for quality and safety & 0.7250 & 6 \\
\hline
\end{tabular}

\section{Project Related Factors}

The most important factor in this group was construction method, followed by Health and safety (accidents); and Working within a confined space (Table 9). Construction method was ranked in position 4 of all 68 factors negatively affecting construction productivity in Afghanistan. This result is supported by Thomas and Sanders (1991), who found that construction method and project features have a high impact on construction productivity. The result can be justified as lack of labour skill, which is ranked in position 2 of manpower related factors, highly inter-related with construction method.

Health and safety with an importance index of 0.800 ranked in position 2 of project related factors. Health and Safety ranked among the 10 most important factors negatively affecting construction productivity in Afghanistan. These results were supported by Thomas and Sanders (1991), who found that accidents have a significant impact on labour productivity.

Table 9. Ranking Factors under Project Group

\begin{tabular}{lll}
\hline Project Related Factors & Imp Index & Rank \\
\hline Construction method & 0.8375 & 1 \\
\hline Health and safety (accidents) & 0.8000 & 2 \\
\hline Working within a confined space & 0.6375 & 3 \\
\hline
\end{tabular}

\section{Materials and Tools Factors}

The results in Table 10 demonstrate 9 factors in the Materials/Tools Group and were ranked according to their importance. Findings indicate that Low quality of raw materials with an importance index of 0.8375 is the most important of all Materials and Tools factors. This factor ranked in position of 5 all 68 factors affecting Construction productivity in Afghanistan. Delay in material's deliveries to site is ranked in position 2 of Materials/Tools Group. This is mainly due to the security problem in the country, which cause road closure to the construction site, as well as lack of adequate infrastructures can be the reason for delay in materials delivery.

Results also indicate that the Shortage of materials are not considered to be as important as other factors, and were ranked in position of 10 of all 68 factors. While, shortage of material in the Gaza Strip (Enshassi et al, 2007), Iran (Zakeri et al, 1996), Indonesia (Kaming et al, 1997) discovered as the most important factors affecting construction productivity. The result might be justified, due to the security and corruption 
problems in the country, which are ranked, respectively, in position of 1 and 2 of all 68 factors, are outweigh to the shortage of materials.

Table 10. Ranking Factors under Materials and Tools Group

\begin{tabular}{lll}
\hline Materials and Tools Factors & Imp & Rank \\
\hline Low quality of raw materials & 0.8375 & 1 \\
\hline Delays in materials' deliveries to site & 0.8125 & 2 \\
\hline Materials' Shortages & 0.8000 & 3 \\
\hline Tools and equipment shortage & 0.7714 & 4 \\
\hline High quality of required work & 0.7250 & 5 \\
\hline Inefficiency of equipment & 0.7067 & 6 \\
\hline Delays due to interference with other crews & 0.7000 & 7 \\
\hline Incidences (e.g. equipment breakdown, planning errors) & 0.7000 & 8 \\
\hline Congested work area & 0.6500 & 9 \\
\hline
\end{tabular}

\section{Overall Ranks of All Factors}

The result in table 11 demonstrate that 6 factors of all 68 factors identified as the most important factors negatively affecting Construction productivity in Afghanistan, which are ranked according to their importance as follows; Security (Crime, theft and disorder), Corruption, Poor Scheduling and Coordination, Construction method, Low quality of raw materials, and Payment delay. On the other hand, results indicate that Labour dissatisfaction, Lack of places for eating and relaxation for labours, Changing Workers, Labour Disruption (e.g. manpower shortages, strikes), and Increase of labourer age were identified as the 5 lowest factors negatively affecting construction productivity.

Table 11. Overall Ranking of Factors

\begin{tabular}{lll}
\hline Factors & Imp Index & Rank \\
\hline Security (Crime, theft and disorder) & 0.938 & 1 \\
\hline Corruption & 0.871 & 2 \\
\hline Poor Scheduling and Coordination & 0.838 & 3 \\
\hline Construction method & 0.838 & 4 \\
\hline Low quality of raw materials & 0.838 & 5 \\
\hline Payment delay & 0.813 & 6 \\
\hline Drawings and specifications alteration during execution & 0.813 & 7 \\
\hline Delays in materials' deliveries to site & 0.813 & 8 \\
\hline Health and safety (accidents) & 0.800 & 9 \\
\hline Materials' Shortages & 0.800 & 10 \\
\hline Financial Incentives & 0.788 & 11 \\
\hline Buildability ( design of a building facilitates ease of construction ) & 0.788 & 12 \\
\hline Rework & 0.788 & 13 \\
\hline Type of project bidding and award (negotiation, lowest bidder,) & 0.771 & 14 \\
\hline Tools and equipment shortage & 0.771 & 15 \\
\hline Lack of Equipment & 0.763 & 16 \\
\hline Transportation and mobilization to construction site & 0.763 & 17 \\
\hline Market inflation & 0.750 & 18 \\
\hline Specification and standardisation & 0.750 & 19 \\
\hline
\end{tabular}




\begin{tabular}{|c|c|c|}
\hline Access to Finance & 0.738 & 20 \\
\hline Lack of training sessions for labours & 0.733 & 21 \\
\hline Supervisors' absenteeism & 0.733 & 22 \\
\hline Augmentation of Government regulations & 0.725 & 23 \\
\hline Project cycle (tendering process) & 0.725 & 24 \\
\hline Lack of competition & 0.725 & 25 \\
\hline Construction law and regulation for quality and safety & 0.725 & 26 \\
\hline High quality of required work & 0.725 & 27 \\
\hline Lack of Skill (Lack of labour experience) & 0.713 & 28 \\
\hline Stoppages because of insolvency of subcontractors / suppliers & 0.713 & 29 \\
\hline Availability of project managers & 0.713 & 30 \\
\hline Inspection Delays & 0.707 & 31 \\
\hline Inefficiency of equipment & 0.707 & 32 \\
\hline Delays due to interference with other crews & 0.700 & 33 \\
\hline Incidences (e.g. equipment breakdown, planning errors) & 0.700 & 34 \\
\hline Stoppages because of disputes with owners / consultants & 0.688 & 35 \\
\hline Judicial system for construction disputes & 0.667 & 36 \\
\hline Access to utilities (Electricity, Water) & 0.663 & 37 \\
\hline Communication Problems With Foreign Workers & 0.657 & 38 \\
\hline Stoppages because of work being rejected by consultants & 0.650 & 39 \\
\hline Congested work area & 0.650 & 40 \\
\hline Misunderstanding between labour/ superintendents & 0.643 & 41 \\
\hline Stop work orders because of infringements of government & 0.640 & 42 \\
\hline Interference from other crew trades or other crew members & 0.640 & 43 \\
\hline Local people cooperation (warlords influence) & 0.638 & 44 \\
\hline Difficulty in Recruitment of Supervisors & 0.638 & 45 \\
\hline Lack of labour surveillance & 0.638 & 46 \\
\hline Working within a confined space & 0.638 & 47 \\
\hline Inclement Weather (require work stoppage of one day or more) & 0.625 & 48 \\
\hline Fatigue & 0.625 & 49 \\
\hline Lack of periodic meeting with labour & 0.625 & 50 \\
\hline Access to land & 0.613 & 51 \\
\hline Types of construction contract & 0.613 & 52 \\
\hline Work Overtime & 0.588 & 53 \\
\hline Stop-work orders because of site accidents & 0.588 & 54 \\
\hline Changing Supervisors & 0.563 & 55 \\
\hline Crew Size & 0.550 & 56 \\
\hline High Rate of Labor Turnover & 0.547 & 57 \\
\hline Natural disaster (floods, hurricane, landslide) & 0.543 & 58 \\
\hline Difficulty in Recruitment of Workers & 0.538 & 59 \\
\hline Misunderstanding among labour & 0.538 & 60 \\
\hline Labour personal problems & 0.538 & 61 \\
\hline Absenteeism at Worksite & 0.533 & 62 \\
\hline Labour disloyalty & 0.525 & 63 \\
\hline Labour dissatisfaction & 0.520 & 64 \\
\hline Lack of places for eating and relaxation for labours & 0.507 & 65 \\
\hline Changing Workers & 0.500 & 66 \\
\hline Labour Disruption (e.g. manpower shortages, strikes) & 0.500 & 67 \\
\hline Increase of labourer age & 0.488 & 68 \\
\hline
\end{tabular}




\section{Comparing Productivity Problem}

Productivity problems are differed from country to country. In order to compare the results obtained previously in other countries with the result of this study, six factors have been selected, which were also highlighted by other authors in Gaza Strip (Enshassi et al, 2007), Iran (Zakeri et al, 1996) and UK (Kaming et al., 1997). It was revealed that lack of materials, which is the most important problem in the UK, Gaza Strip, and Iran, is relatively not important in Afghanistan, and was ranked in position of 10 of all 68 factors. This might be due to lack of security and lack of capacity in public and private sector which are found to be more serious in Afghanistan than the comparator countries. It is reasonable to conclude that Afghanistan and Gaza Strip have fewer problems with absenteeism, while it is ranked $6^{\text {th }}$ and $7^{\text {th }}$ in the UK and Iran respectively. Considering developed and developing countries separately, it was concluded that developing countries suffer more from rework at about the same level.

Table 12. Productivity Problems in Several Countries

\begin{tabular}{lcccc}
\hline Productivity Problems & Rank & Rank & Rank & Rank \\
\cline { 2 - 5 } & UK & Iran & Gaza Strip & Afghanistan \\
\hline Lack of material & 1 & 1 & 1 & 10 \\
\hline Interference & 2 & 12 & 24 & 33 \\
\hline Rework & 3 & 10 & 11 & 13 \\
\hline Supervision delays & 4 & 6 & 8 & 22 \\
\hline Lack of equipment & 5 & 5 & 10 & 16 \\
\hline Absenteeism & 6 & 7 & 41 & 62 \\
\hline
\end{tabular}

\section{Ranking Groups Negatively Affecting Construction Productivity}

The 7 groups of factors that affect construction productivity are ranked in table 13. It is noted that design factors with an importance index of 0.7666 ranked in position of 1 of all 7 group factors. This result is justified, as the separation of design and build in procurement process, which is a common practice in Afghanistan, causing alteration of drawings and specifications during the implementation of the projects. Also it was found that Buildability and rework is arising as a consequence of the separation of design and build.

Project related factors with an importance of 07583 are ranked in position of 2 . This result is acceptable due to the lack of skill and lack of capacity in public and private sector, which are more serious in Afghanistan

Table 23. Ranking Factors Negatively Affecting Productivity among Groups

\begin{tabular}{lll}
\hline Factors Group & Imp Index & Rank \\
\hline Design factors & 0.7660 & 1 \\
\hline Project related factors & 0.7583 & 2 \\
\hline Materials and tools factors & 0.7448 & 3 \\
\hline Procurement related Factors & 0.7304 & 4 \\
\hline External Factors & 0.7062 & 5 \\
\hline Management factors & 0.6721 & 6 \\
\hline Manpower related Factors & 0.5715 & 7 \\
\hline
\end{tabular}




\section{Recommendations}

Although, lack of security and corruption is ranked in position of 1 and 2 of all 68 factors negatively affecting construction productivity in Afghanistan but, the research revealed that most of the problems are related to Design and Project groups. Lack of Construction Company's managerial and technical capacity coupled with lack of integration between design and build found to be the most important factors negatively affecting construction productivity in Afghanistan after security and corruption. Separation of design and build in most capital projects are responsible for most of the problems causing alteration of drawings and contracts, and rework. The study concludes that the level of productivity can be improved if the construction stakeholders (Public and Private) achieve the followings:

- Fight corruption and improve security

- Introducing of new procurement method such as PPP/PFI in major capital projects in order to facilitate integration between design and construction.

- Developing of new codes for engineering design

- Enforcement of quality standards to construction projects

- Increase the level of technical and managerial skills of site managers and engineers by providing long term and short term trainings.

- Adequate scheduling and programming

- Adequate assessment of risks and constraints such as security, alteration of design and payment delay before undertaking of construction projects.

\section{Conclusion}

The aim of this paper was to identify factors influencing construction productivity in Afghanistan, and to rank these factors according to their relative importance from the construction stakeholder's point of view within the Afghanistan construction industry. The research confirms that Afghanistan like many other developing countries is suffering from poor productivity. These findings should enable construction stakeholders to easily identify their strengths and weaknesses and apply new techniques to reduce the negative impact of the factors, which leads to increased project productivity. The result indicates that the main 10 factors negatively influencing construction productivity in Afghanistan are;

$\begin{array}{llll}1 & \text { Security (Crime, theft and disorder) } & 6 & \text { Payment delay } \\ 2 & \text { Corruption } & 7 & \text { Drawings and specifications } \\ 3 & \text { Poor Scheduling and Coordination } & 8 & \text { Delays in materials' deliveries to } \\ 4 & \text { Construction method } & 9 & \text { Health and safety (accidents) } \\ 5 & \text { Low quality of raw materials } & 10 & \text { Materials' Shortages }\end{array}$

It was revealed that lack of materials, which is the most important factor influencing construction productivity in the UK, Gaza Strip, and Iran, is relatively not important in Afghanistan, ranked in position of 10 of all 68 factors. Instead security and corruption coupled with lack of capacity in public and private sector, and lack of integration between design and build identified as the most important factors negatively influence construction productivity in the country. In addition, 68 factors considered in the study were divided into seven groups, which were ranked according to their importance index.

1. Design factors

2. Project related factors

3. Materials and tools factors

4. Procurement related Factors
5. External Factors

6. Management factors

7. Manpower related Factors 


\section{References}

Abdul Kadir. M., R, et al (2005), Factors affecting construction labour productivity for Malaysian residential projects, Journal of Structural Survey, Vol. 23 No. 1, pp. 42-54

AISA (2008), AISA annual report 2008, Afghanistan Investment Support Agency, Kabul

Altaf, H. (1979), Construction productivity factors, Journal of Professional Activities, ASCE, 105(E14), p. 180-195

Aniekwu, A. N. \& Okpala, C. D. (1988), The effect of systemic factors on contract services in Nigeria, Construction Management and Economics, Volume 6, p.171-182

Assaf, S. A. et al. (1995), Causes of delay on large building construction projects, Journal of Management in Engineering, Volume 11(2), p. 45-50

Enshassi, A. et al, (2007), Factors affecting labour productivity in building projects in Gaza Strip, Journal of Civil Engineering and Management, Vol 13, No 4, pp. 245-254

Herbsman, Z \& Ellis, R, (1990), Research of factors influencing construction productivity, Construction Management and Economics, Vol. 8 No. 1, pp. 49-61

Kaming, P. F. et al. (1997), Factors influencing craftsman's productivity in Indonesia, International Journal of Project Management, Volume 15(1), p. 21-30

Lema, N. M. (1995), Construction of labour productivity modelling. University Of Dar Elsalaam

Makulsawatudom, A and Margaret, E (2001), Factors affecting the productivity of the construction industry in Thailand: The craftsmen's perception, COBRA Conference Papers

Mansfield, N. R. et al. (1994), Causes of delays and cost overruns in Nigerian construction project, International Journal of Project management, 12, p. 254-260

Olomolaiye. P. O, Jayawaradane. A. K.W and Harris. F. C (1998), Construction productivity management, $1^{\text {st }}$ ed. England: Englemere Limited

Rojas E.M. and Aramvareekul P. (2003), Labour productivity drivers and opportunities in the construction industry, Journal of Management in Engineering, 19 (2), 78-82

SIGAR (2010) Contract delays led to cost overruns for the Kabul Power Plant and sustainability remains a key challenge, SIGAR Report, Kabul

Tangen, S (2005) Demystifying productivity and performance, International Journal of Productivity and Performance Management, Vol. 54 Issue: 1, pp.34 - 46

Thomas, H. R. (1999), Construction baseline productivity: theory and practice. Journal of Construction Management and Engineering, ASCE, 125(5), p. 295-303.

Thomas, H. R.; Sanders, S. R. (1991), Factors affecting masonry productivity, Journal of Construction Engineering and Management, ASCE, 117(4), p. 626-644.

UNODC\&UNOPS (2007), Prison construction and rehabilitation findings and recommendations, 2007 Report, Kabul

Wilcox, S., Stringfellow, B., Harris, R., Martin, B. (2000) Management and productivity, Transportation Research Board, Committee on Management And Productivity, USA

World Bank (2009a), Fighting corruption in Afghanistan, World Bank Publication

World Bank (2009b), The Afghanistan Investment Climate, World Bank Publication

Yong, P. M. H., Lansley, P. R \& Harlow, P. A. (1987), Turnkey construction for building in Malaysia, Managing Construction Worldwide, Vol. II Proceedings of CIOB, CIB W 65, London, 7th -10th September, Volume 2, p. 284-295.

Zakeri, M. et al. (1996), A Survey of Constraints on Iranian Construction Operative's Productivity, Construction Management and Economics, Vol 14, p. 417-426 